\title{
PENGARUH PRE GELATINISASI TERHADAP KARAKTERISTIK TEPUNG SINGKONG
}

\author{
(Influence of Pre Gelatinization to Characteristics of Cassava Flour) \\ Hapsari Titi P, A. Zainul A, M. Nugroho
}

\begin{abstract}
ABSTRAK
Selama ini tepung singkong masih terbatas penggunaannya, karena secara umum dibatasi oleh sifat fisik dan kimia-nya. Tepung singkong terbuat dari potongan ubi kayu yang telah kering. Tepung Pre gelatinisasi adalah tepung yang mengalami proses gelatinisasi dengan perebusan (parboiling) dan selanjutnya dikeringkan, sehingga memperbaiki kualitas, sifat reologi dan pasta tepung. Tujuan penelitian adalah mempelajari pembuatan dan karakteristik tepung singkong pre gelatinisasi dan pengaruh suhu pre-gelatinisasi $100^{\circ} \mathrm{C}, 90^{\circ} \mathrm{C}, 80^{\circ} \mathrm{C}$ terhadap karakteristik tepung singkong . Penelitian ini terdiri dari 4 perlakuan yaitu $\mathrm{A}=$ Tanpa pre gelatinisasi, $\mathrm{B}=$ Pre gelatinisasi pada suhu $100^{\circ} \mathrm{C}, \mathrm{C}=$ Pre gelatinisasi pada suhu $90^{\circ} \mathrm{C}, \mathrm{D}=$ Pre gelatinisasi pada suhu $80^{\circ} \mathrm{C}$.

Dari analisa statistik terdapat perbedaan nyata perlakuan tanpa pre gelatinisasi dan pre gelatinisasi terhadap karakteristik kadar air, kadar HCN, kadar amilosa, derajat putih, organoleptik, dan sifat amilografi. Perlakuan pre gelatinisasi mampu menurunkan suhu dan waktu awal gelatinisasi, suhu dan waktu gelatinisasi (saat granula pecah), viskositas dingin, dan viskositas balik. Analisa statistik terhadap perlakuan suhu pre gelatinisasi $100^{\circ} \mathrm{C}, 90^{\circ} \mathrm{C}$, $80^{\circ} \mathrm{C}$ memberikan pengaruh yang berbeda nyata, kadar amilosa, derajat putih, dan penerimaan organoleptik (warna, kenampakan, dan aroma) terhadap sifat amilografi.
\end{abstract}

Kata kunci : pre gelatinisasi, tepung singkong, sifat amilografi

\section{ABSTRACT}

The use of cassava flour is still very limited until nowadays, because it is constrained by its physical and chemical properties. Cassava flour is made from dried cassava chips traditionally. Pre gelatinized cassava flour is obtained from complete gelatinization process using parboiling technique and then to be dried to improve their quality, rheology and pasting behavior. The objective of the research is to study the production and characteristic of pre gelatinized cassava flour and the influence of various temperatures e.g. $100^{\circ} \mathrm{C}, 90^{\circ} \mathrm{C}, 80^{\circ} \mathrm{C}$ to cassava flour properties. This research consists of 4 treatments, those are $\mathrm{A}=$ Non pre gelatinization, $\mathrm{B}=$ Pre gelatinization at temperature of $100^{\circ} \mathrm{C}, \mathrm{C}=$ Pre gelatinization at temperature of $90^{\circ} \mathrm{C}$, and $\mathrm{D}=$ 
Pre gelatinization at temperature of $80^{\circ} \mathrm{C}$.

Statistical analysis reveal difference significant between non pre gelatinization and pre gelatinization flour of water content, HCN content, amylase content, whiteness, organoleptic attribute and the amilographic characteristics. Pre gelatinization treatment will be able to decrease initial temperature and time of gelatinization, peak time and temperature of gelatinization, cold viscosity and set back viscosity. Statistical analysis of various temperature of pre gelatinization i.e. $100^{\circ} \mathrm{C}, 90^{\circ} \mathrm{C}, 80^{\circ} \mathrm{C}$ showed significant difference of amylase content, whiteness, and organoleptic attribute and pasting behavior characteristics

Key words : pre gelatinization, cassava flour, amilograph properties

\section{PENDAHULUAN}

Tanaman singkong (Manihot esculenta Crantz) banyak tumbuh di Indonesia, karena tanaman ini mempunyai sifat yaitu mudah tumbuh di daerah tropis, tahan terhadap suhu tinggi, hasil produksi besar dan tidak mudah terserang hama dan penyakit. Umbi singkong merupakan sumber karbohidrat yang sangat tinggi, sehingga mampu menyediakan energi dalam jumlah yang cukup besar dan rendah kadar lemaknya. Usaha diversifiaksi pangan yang diprogramkan pemerintah dengan tidak menggantungkan terhadap bahan pangan dari serealea (padi, jagung, gandum) berpotensi mengangkat potensi dari singkong.

Umbi singkong dapat dimanfaatkan dalam beberapa bentuk makanan jadi atau setengah jadi (intermediate). Pengolahan singkong menjadi tepung dapat meningkatkan nilai tambah dan kegunaan singkong, serta memperpanjang masa simpannya. Chuzel, Zakhia and Cereda (1994) menyatakan bahwa beberapa produk antara (intermediate) singkong (chips, tepung, dan pati) merupakan sumber nutrisi untuk manusia dan ternak, serta bahan baku berbagai macam industri makanan seperti roti dan kerupuk. Singkong mengandung komponen toksik dalam bentuk glukosa sianogenik, tetapi kadarnya dapat diturunkan atau dihilangkan melalui beberapa proses seperti perebusan, perendaman, fermentasi dan pengeringan.

Tepung singkong terbuat dari potongan ubi kayu yang telah kering kemudian dihaluskan. Selama ini tepung singkong masih terbatas penggunaannya, karena secara umum dibatasi oleh sifat fisik dan kimia-nya. Pati pre gelatinisasi adalah pati yang mengalami proses gelatinisasi dan selanjutnya dikeringkan. Pati ini akan mengalami perubahan sifat fisik dan sifat pati alami. Menurut Padmaja et. al. (1996) modifikasi tepung secara pre gelatinisasi dengan perebusan (parboiling) dapat memperbaiki karakteristik dari pasta tepung. 
Temperatur merupakan salah satu faktor penting yang mempengaruhi proses pre gelatinisasi. Jika pati tidak dipanaskan pada temperatur yang sesuai maka derajat pengembangan granula pati tidak tepat dan tidak memberikan sifat yang diinginkan.

Tujuan penelitian ini adalah mempelajari karakteristik antara tepung singkong yang dibuat dengan tanpa pre gelatinisasi dan pre gelatinisasi; serta mempelajari pengaruh temperatur pre gelatinisasi terhadap karakteristik fisik, kimia dan fungsional tepung singkong.

\section{METODOLOGI PENELITIAN}

Penelitian dilaksanakan mulai bulan April sampai Juli 2007, di labolatorium Teknologi Hasil Pertanian Universitas Yudharta.

Bahan baku penelitian adalah singkong varietas UJ berumur 8 bulan yang diperoleh dari Balitkabi (Balai Penelitian Kacang-kacangan dan Umbiumbian) Malang. Alat yang digunakan adalah pemanas, termometer, timbangan, pengiris singkong, alat penepung, ayakan, loyang, oven, maffel furnace, centrifuge, Viscoamilograph, Colorimeter.

Penelitian ini menggunakan rancangan percobaan Rancangan Acak Kelompok (RAK) faktor tunggal, diulang 3 kali. Terdiri dari 4 perlakuan yaitu $\mathrm{A}=$ Tanpa pre gelatinisasi, $\mathrm{B}=$ Pre gelatinisasi pada suhu $100^{\circ} \mathrm{C}, \mathrm{C}=$ Pre gelatinisasi pada suhu $90^{\circ} \mathrm{C}, \mathrm{D}=$ Pre gelatinisasi pada suhu $80^{\circ} \mathrm{C}$ : Dari 4 perlakuan disusun 3 pembandingan linier ortogonal kontras yaitu:

1. A vesus $B C D$, berarti melihat apakah terdapat perbedaan karakteristik tepung singkong antara perlakuan tanpa pre gelatinisasi dan pre gelatinisasi.

2. $B$ versus $C$

Melihat apakah terdapat perbedaan karakteristik tepung singkong antara perlakuan suhu $100^{\circ} \mathrm{C}$ dan $90^{\circ} \mathrm{C}$.

3. $C$ versus $D$

Melihat apakah terdapat perbedaan karakteristik tepung singkong antara perlakuan suhu $90^{\circ} \mathrm{C}$ dan $80^{\circ} \mathrm{C}$.

Pelaksanaan Penelitian meliputi :

1. Pembuatan tepung singkong tanpa pre gelatinisasi :
a. Pencucian dan pengupasan singkong
b. Pengirisan ukuran $1 \mathrm{~cm}$
c. Pengeringan selama 24 - 36 jam
d. Penggilingan dan pengayakan
e. Tepung singkong

2. Pembuatan tepung singkong pre gelatinisasi

a. Pencucian dan pengupasan

b. Pengirisan ukuran $1 \mathrm{~cm}$

c. Pemanasan (parboiling) dalam air, selama 10 menit (temperatur $80^{\circ} \mathrm{C}, 90^{\circ} \mathrm{C}$, dan $100^{\circ} \mathrm{C}$ )

d. Pembuangan air (decanting)

e. Pengeringan selama 24 - 36 jam

f. Penggilingan dan pengayakan

g. Tepung singkong

Baku singkong dilakukan analisa proksimat meliputi kadar air, serat kasar, kadar lemak, kadar HCN, kadar pati, kadar protein (AOAC, 1989). Tepung singkong dilakukan analisa pada kadar air, kadar pati, kadar amilosa, kadar HCN, warna (whiteness tester) pembanding $\mathrm{BaSO}_{4} \quad 100 \%$ (AOAC, 1989). Sfat amilografi tepung 
singkong dianalisa menggunakan Viscoamilograph untuk mengukur suhu gelatinisasi, waktu gelatinisasi dan viskositas. Analisa organoleptik meliputi parameter warna, kenampakan dan aroma (Larmond, 1984).

Analisis data dilakukan secara statistik menggunakan analisis sidik ragam (uji $F$ ) dengan selang kepercayaan 5\% dan 1\%. Dan dilakukan uji pembandingan linier orthogonal kontras untuk membandingkan antar perlakuan (Sastrosupadi, 1999). Untuk organoleptik menggunakan uji acceptance (tingkat penerimaan) terdiri 15 panelis. Data yang diperoleh dianalisis menggunakan analisis sidik ragam (uji F) dan pembandingan linier orthogonal kontras (Larmond, 1984).

\section{HASIL DAN PEMBAHASAN Kadar Air}

Rerata kadar air tepung singkong pada penelitian ini berkisar antara $11.9267 \%$ sampai 14.7067 \% (Gambar 1). Menurut Ananymous (2000) kadar air tepung tapioka setelah pengeringan berkisar antara 12-13\%

Berdasarkan analisis ragam (pembandingan linier ortogonal) perlakuan pre gelatinisasi pada tepung singkong memberikan penurunan kadar air tepung secara nyata dibandingkan tepung tanpa pre gelatinisasi. Menurunnya kadar air pada tepung pre gelatinisasi disebabkan karena perlakuan pre gelatinisasi secara parboiling (perebusan) memberikan pemanasan yang menyebabkan terjadinya penyerapan air dan

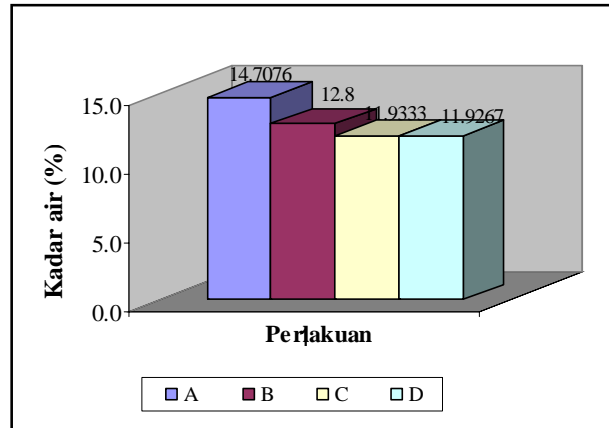

Keterangan:

$\mathrm{A}=$ Tepung Tanpa Pre gelatinisasi,

$\mathrm{B}=$ Tepung Pre Gelatinisasi $100^{\circ} \mathrm{C}$

$\mathrm{C}=$ Tepung Pre Gelatinisasi $90^{\circ} \mathrm{C}$

$\mathrm{D}=$ Tepung Pre Gelatinisasi $80^{\circ} \mathrm{C}$

\section{Gambar 1. Grafik Rerata Kadar Air Tepung Singkong}

pembengkakan granula pati.

Pemanasan menyebabkan lemahnya ikatan hidrogen dalam granula, sehingga granula yang telah membengkak memiliki ukuran yang besar dan bersifat irreversibel. Ketika dilakukan proses pengeringan tepung yang telah tergelatinisasi, air mudah lepas dari ikatan hidroksil sehingga kadar air sedikit menurun. Menurut Kenneth, Leon and J Peter (1991) penggunaan panas yang terus meningkat menyebabkan ikatan hidrogen intermolukuler antara rantai amilosa dan rantai cabang amilopektin mulai melemah, sehingga granula pati mengembang secara cepat. Granula yang telah mengembang mempunyai struktur yang lebih lunak dan bersifat irreversibel.

Perlakuan pre gelatinisasi pada suhu yang berbeda $80^{\circ} \mathrm{C}, 90^{\circ} \mathrm{C}$, dan $100^{\circ} \mathrm{C}$ tidak memberikan pengaruh yang nyata 
pada kadar air tepung. Perlakuan tersebut merupakan suhu dimana telah terjadi proses gelatinisasi dan pembengkakan granula. Berdasarkan analisis amilografi, tepung singkong pre gelatinisasi telah mengalami gelatinisasi pada suhu sekitar $80^{\circ} \mathrm{C}$ (Tabel 1). Ikatan hidrogen melemah sehingga rantai dan struktur pati menjadi lebih lunak. Ikatan hidrogen intramolekuler berfungsi mempertahankan struktur integritas granula pati. Proses pengeringan kembali pati yang telah mengalami gelatinisasi, akan memudahkan terlepasnya air yang terikat didalam granula pati.

\section{Kadar HCN}

Tepung singkong mempunyai rerata kadar HCN ini berkisar antara 10.7833 ppm sampai 14.7860 ppm (Gambar 2).

Berdasarkan analisis ragam dan perbandingan linier ortogonal perlakuan tepung secara pre gelatinisasi memberikan pengaruh yang nyata terhadap kadar HCN, dibandingkan dengan tepung singkong tanpa pre gelatinisasi. Perlakuan pre gelatinisasi menurunkan kadar HCN pada tepung singkong, dibandingkan tepung singkong tanpa pre gelatinisasi. Hal ini disebabkan pada proses pembuatan tepung dengan pre gelatinisasi melalui tahap parboling (perebusan) pada suhu 80-100 ${ }^{\circ} \mathrm{C}$ akan merusak aktivitas enzim linamarase dan melarutkan asam sianogenik. Proses selanjutnya yaitu pembuangan air hasil perebusan menurunkan dan menghilangkan asam sianida.

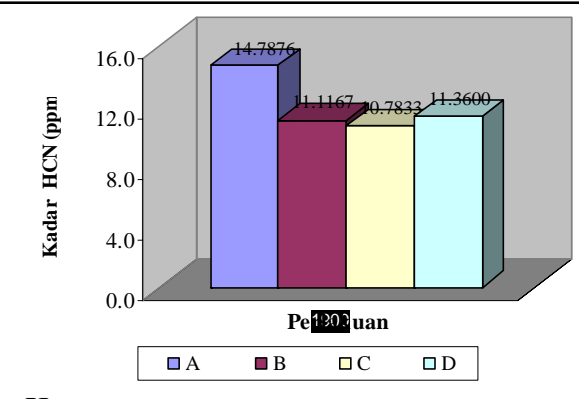

Keterangan:

$\mathrm{A}=$ Tepung Tanpa Pre gelatinisasi,

$\mathrm{B}=$ Tepung Pre Gelatinisasi $100^{\circ} \mathrm{C}$

$\mathrm{C}=$ Tepung Pre Gelatinisasi $90_{\mathrm{O}} \mathrm{C}$

$\mathrm{D}=$ Tepung Pre Gelatinisasi $80_{\mathrm{O}} \mathrm{C}$

\section{Gambar 2. Grafik Rerata Kadar HCN Tepung Singkong}

\section{Beberapa tahap proses pada} pembuatan tepung singkong akan menurunkan HCN. Proses perebusan dalam air mendidih selama 10 menit akan merusak aktivitas enzim linamarase dan melarutkan asam hidrosianida. Proses pembuangan air rebusan (decanting) menurunkan atau menghilangkan kandungan sianida (Balagopalan, 2002). Menurut Padmaja et.al. (1996) HCN merupakan komponen toksik yang terdapat dalam singkong dalam bentuk glukosa sianogenik. Seluruh cultivar singkong mengandung HCN berkisar natara 10500 ppm. Keracunan yang serius terjadi bila kandungan HCN melebihi batas 150 ppm.

Perlakuan pre gelatinisasi pada suhu yang berbeda $80^{\circ} \mathrm{C}, 90^{\circ} \mathrm{C}$, dan $100^{\circ} \mathrm{C}$ tidak memberikan perbedaan yang nyata pada kadar HCN tepung singkong. Hal ini menunjukkan pada suhu $80^{\circ} \mathrm{C}$ sudah dapat menurunkan 
kadar HCN tepung singkong, walaupun pemanasan pada suhu $90^{\circ} \mathrm{C}$ memberikan kadar HCN terendah yaitu 10.7833 ppm. Tahapan proses pada pembuatan tepung singkong seperti pemanasan menggunakan dan pembuangana air rebusan (decanting) melarutkan kandungan asam sianida.

\section{Kadar Pati}

Tepung singkong mempunyai rerata kadar pati ini berkisar antara 76.7400\% sampai 81.3533\% (Gambar 3). perlakuan pre gelatinisasi tidak

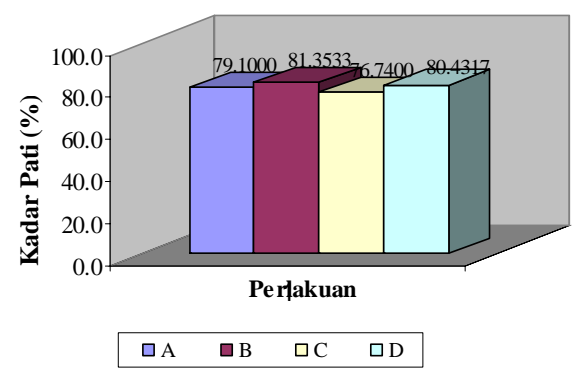

Keterangan:

$\mathrm{A}=$ Tepung Tanpa Pre gelatinisasi,

$\mathrm{B}=$ Tepung Pre Gelatinisasi $100^{\circ} \mathrm{C}$

$\mathrm{C}=$ Tepung Pre Gelatinisasi $90^{\circ} \mathrm{C}$

$\mathrm{D}=$ Tepung Pre Gelatinisasi $80^{\circ} \mathrm{C}$

Gambar 3. Grafik Rerata Kadar Pati Tepung Singkong

memberikan pengaruh yang nyata terhadap kadar pati tepung singkong, dibandingkan dengan perlakuan tanpa pre gelatinisasi. Berdasarkan perbandingan linier ortogonal tepung singkong dengan perlakuan yang berbeda (pre gelatinisasi dan tanpa pr gelatinisasi) mempunyai kadar pati

yang hampir sama. Kondisi ini menunjukkan bahwa perlakuan pre gelatinisasi tidak mempengaruhi jumlah pati yang terdapat dalam tepung singkong.

Berdasarkan analisis ragam dan perbandingan linier ortogonal perlakuan suhu pre gelatinisasi yang berbeda yaitu $80,90,100^{\circ} \mathrm{C}$ tidak memberikan pengaruh yang nyata pada kadar pati tepung singkong. Tepung singkong mempunyai kisaran kadar pati dalam jumlah hampir sama.

\section{Kadar Amilosa}

Rerata kadar air amilosa tepung singkong singkong berkisar antara 20.3397 \% sampai 21.7303 \% (Gambar 4.)

Berdasarkan analisis ragam perlakuan dan perbandingan linier ortogonal pre gelatinisasi memberikan pengaruh yang nyata terhadap kadar

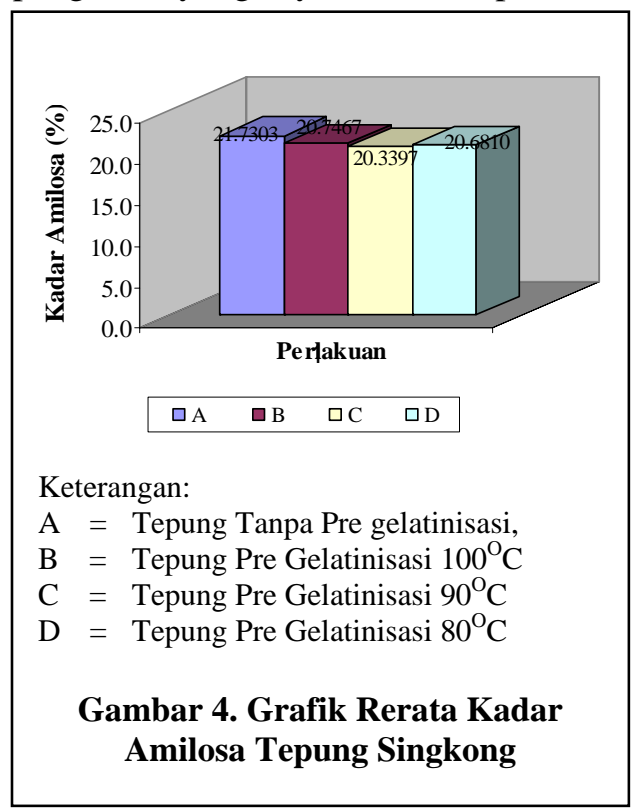


amilosa tepung dibandingkan tanpa pre gelatinisasi. Perlakuan pre gelatinisasi sedikit menurunkan kadar amilosa tepung singkong. Hal ini disebabkan ketika pati dipanaskan dalam air pada temperatur gelatinisasi, energi panas menyebabkan ikatan hidrogen pati menjadi melemah. Ikatan yang lemah memudahkan air masuk ke dalam granula dan memungkinkan sedikit melarutnya dan terjadi pertukaran molekul amilosa menuju ke air.

Berdasarkan perbandingan ortogonal perlakuan suhu pre gelatinisasi 80,90 , dan $100^{\circ} \mathrm{C}$ tidak memberikan perbedaan yang nyata terhadap kadar amilosa tepung singkong. Hal ini disebabkan suhu yang digunakan pada perlakuan ini merupakan suhu diatas suhu gelatinisasi tepung singkong. Pada kisaran temperatur tersebut proses gelatinisasi pati telah berlangsung, sehingga telah terjadi pertukaran molekul amilosa ke air, dan pati masih dalam fragmen yang melingkupi. Annison dan Topping (2000) menyatakan bahwa gelatinisasi terdiri dari dua tahap proses yaitu suspensi pati yang dipanaskan pada suhu 60$70^{\circ} \mathrm{C}$ sebagian granula akan mengembang. Ketika suhu dinaikkan menjadi $90^{\circ} \mathrm{C}$ granula akan mengembang seluruhnya dan kehilangan bentuknya, meskipun pati masih terdiri dari suatu fragmen yang melingkupinya.

\section{Derajat Putih}

Rerata derajat putih tepung singkong berkisar antara 69.5667\% sampai 74.100\% (Gambar 5).
Berdasarkan analisis ragam perlakuan pre gelatinisasi memberikan pengaruh yang sangat nyata

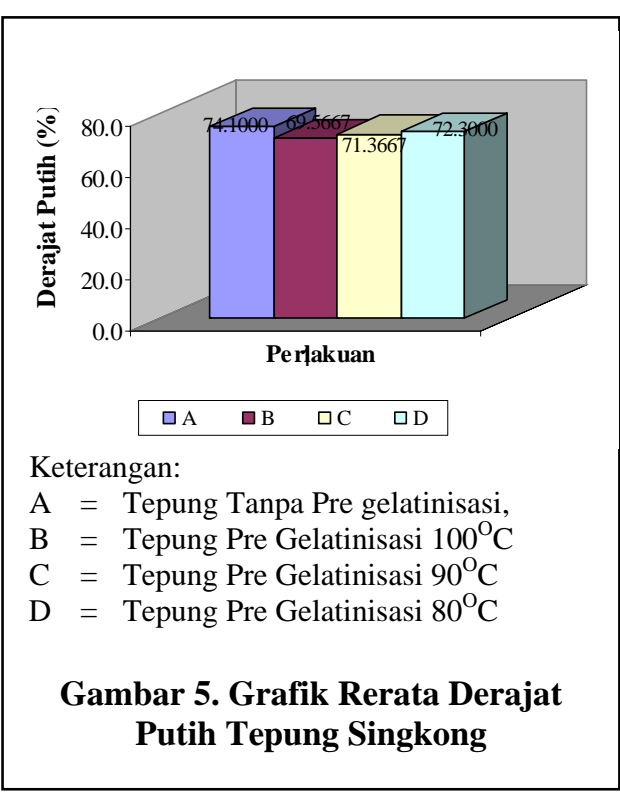

dibandingkan tanpa pre gelatinisasi dan berdasarkan perbandingan ortogonal terdapat perbedaan derajat putih tepung pre gelatinisasi dan tanpa gelatinisasi. Kondisi ini disebabkan oleh proses pemanasan pada pre gelatinisassi akan melarutkan beberapa komponen kimia dalam tepung dan sel pati seperti gula, amilosa, protein. Proses pengeringan kembali pati yang tergelatinisasi memungkinkan senyawa-senyawa terlarut tersebut, seperti gula perduksi dan protein bereaksi menghasilkan pigmen berwarna coklat.

Berdasarkan perbandingan linier ortogonal perlakuan pre gelatinisasi pada suhu yang berbeda memberikan pengaruh yang sangat nyata terhadap derajat putih tepung singkong. Suhu $100^{\circ} \mathrm{C}$ memberikan nilai derajat putih 
tepung yang lebih rendah dibandingkan perlakuan pr gelatinisasi suhu $90^{\circ} \mathrm{C}$, dan pre gelatinisasi $80^{\circ} \mathrm{C}$ memberikan derajat putih yang lebih tinggi dibandingkan pre gelatinisasi pada suhu $90^{\circ} \mathrm{C}$. Kondisi ini disebabkan semakin tinggi suhu pre gelatinisasi akan semakin melarutkan komponen kimia dalam sel, sehingga memungkinkan gula dan protein untuk bereaksi menghasilkan pigmen berwarna coklat.

Kandungan utama singkong adalah karbohidrat yang sebagian besar merupakan pati, tetapi pada umumnya sedikit mengandung protein. Komponen kimia tepung singkong adalah pati, serat, gula, lemak, protein dan sejumlah kecil komponen lain (Moorthy, Rickard and Blanshard, 1996). Menurut Anaymous (2000) cairan dalam sel kaya akan kandungan
Belitz and Groszh (1987) interaksi komponen amino dan monosakarida, yang diikuti dengan pelepasan air, akan membentuk senyawa imine intermediary atau $\mathrm{N}$ glikosida. $\mathrm{N}$ glikosida merupakan produk awal yang selanjutnya dapat membentuk senyawa Amadori (Amadori rearrangement) Senyawa ini merupakan produk intermediate, yang selanjunya merupakan rangkaian dari reaksi Maillard yaitu reaksi yang menyebabkan warna coklat pada bahan makanan.

\section{Sifat Amilografi}

Sifat amilografi dari tepung singkong diukur menggunakan alat Viscoamilograph. Sifat amilografi meliputi suhu awal gelatinisasi, waktu awal gelatinisasi, suhu gelatinisasi (saat granula pecah), waktu gelatinisasi

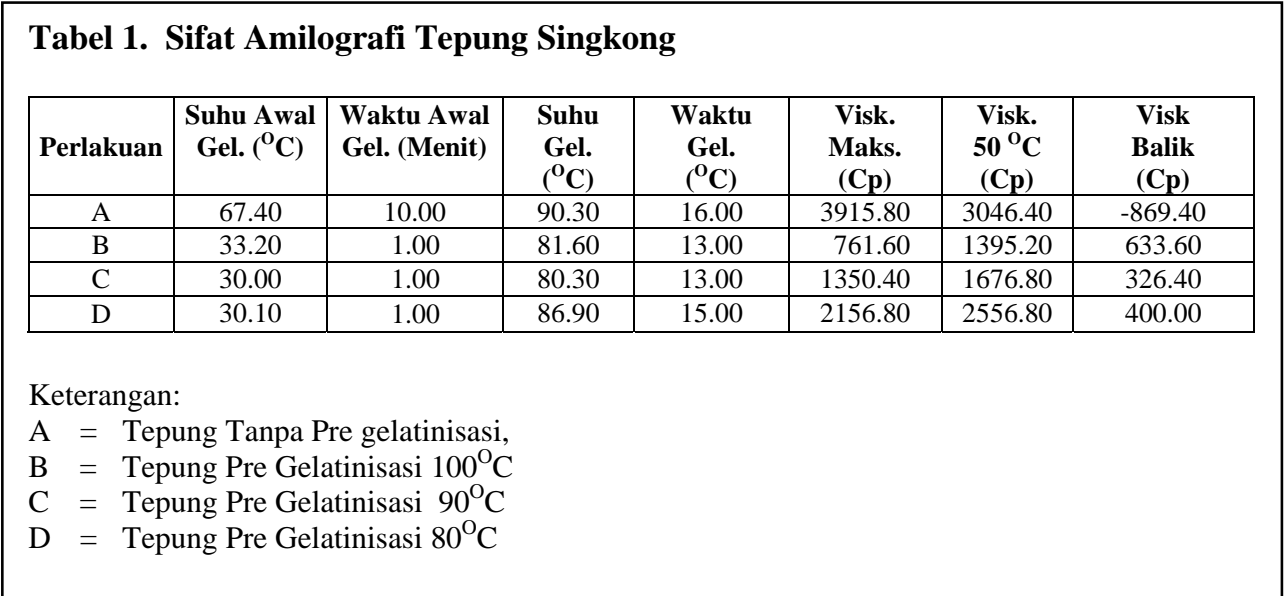

gula dan protein. Proses perusakan sel menyebabkan larutan dalam sel akan keluar berinteraksi dengan udara dan kemudian bereaksi dengan oksigen membentuk komponen warna. Menurut (granula pecah), viskositas maksimum, viskositas dingin, dan viskositas balik (Tabel 1).

Suhu awal gelatinisasi adalah suhu pada saat ikatan mulai melemah 
dan terjadinya pembengkakan granula pati. Tepung singkong tanpa pre gelatinisasi mempunyai suhu dan waktu awal gelatinisasi yang tinggi yaitu $67.40{ }^{\circ} \mathrm{C}$ dan 10 menit. Perlakuan pre gelatinisasi menurunkan suhu dan waktu awal gelatinisasi. Perlakuan pre gelatinisasi pada suhu $80^{\circ} \mathrm{C}, 90^{\circ} \mathrm{C}$ dan $100^{\circ} \mathrm{C}$ mempunyai kisaran suhu awal yang hampir sama yaitu $33.20^{\circ} \mathrm{C}$, $30.00^{\circ} \mathrm{C}$, dan $30.10^{\circ} \mathrm{C}$, dan waktu gelatinisasi yang sama yaitu 1 menit (Tabel 1). Kondisi ini menunjukkan pada suhu tersebut tepung singkong pre gelatinisasi mulai menyerap air dan terhidrasi kembali pada kisaran suhu $30^{\circ} \mathrm{C}$. Perlakuan pre gelatinisasi merubah sifat dari tepung singkong, Tepung yang mengalami pre gelatinisasi memiliki kemampuan menyerap air pada suhu yang lebih rendah, dan ketika terjadi peningkatan suhu maka proses pembengkakan dan pecahnya granula lebih cepat terjadi.

Suhu gelatinisasi adalah suhu pecahnya granula pati karena pembengkakan granula setelah melewati titik maksimum. Secara umum perlakuan pre gelatinisasi akan menurunkan suhu dan waktu gelatinisasi. Pati singkong tanpa pre gelatinisasi mempunyai suhu dan waktu gelatinisasi tertinggi yaitu $90.30^{\circ} \mathrm{C}$ dan 16 menit. Waktu gelatinisasi pada perlakuan suhu pre gelatinisasi 80 dan $90^{\circ} \mathrm{C}$ mempunyai waktu yang yang singkat yaitu 13 menit, dibandingkan pre gelatinisasi $100^{\circ} \mathrm{C}$ yang mempunyai waktu gelatinisasi 15 menit. Penurunan waktu gelatinisasi menunjukkan bahwa proses gelatinisasi pati pada tepung pre gelatinisasi lebih pendek dari pada tanpa pre gelatinisasi. Perlakuan pre gelatinisasi pada suhu 90 dan $100^{\circ} \mathrm{C}$ mempunyai suhu gelatinisasi yang paling rendah yaitu 80.30 dan $81.60^{\circ} \mathrm{C}$. Menurut Daramola dan Osanyinlusi (2005) waktu gelatinisasi yang singkat akan menurunkan biaya, sedangkan suhu gelatinisasi yang rendah akan mempersingkat proses pengolahan.

Tepung yang mengalami pre gelatinisasi dengan perebusan atau (parboling) telah mengalami perubahan struktur ikatan dan bentuk granula. Ikatan hidrogen antara amilosa dan amilopektin melemah karena adanya pemanasan awal. Gelatinisasi mengakibatkan dehidrasi dan konversi dari bentuk amarphous amilosa ke bentuk helik. Bentuk helik menjadi bagian yang lemah dari kristal granula pati. Menurut Zallie (1988) temperatur gelatinisasi dipengaruhi oleh kuat lemahnya ikatan di dalam granula.

Viskositas maksimum adalah titik maksimum viskositas tepung selama proses pemanasan. Viskositas maksimum tepung singkong tanpa pre gelatinisasi adalah $3915.80 \mathrm{Cp}$, yang merupakan nilai tertinggi dibandingkan dengan perlakuan lain. Menurut Daramola dan Osanyinlusi (2005) viskositas tinggi menunjukkan bahwa tepung memiliki water binding (pengikatan air) yang sangat tinggi. Perlakuan pre gelatinisasi menurunkan nilai viskositas tepung singkong, dimana viskositas maksimum adalah 761.60 sampai $2156.80 \quad$ Cp. Nilai viskositas maksimum terendah dimiliki 
oleh perlakuan pre gelatinisasi pada suhu $100^{\circ} \mathrm{C}$ yaitu $761.60 \mathrm{Cp}$.

Perlakuan pre gelatinisasi mampu mengubah puncak kurva amilograf tepung singkong (Gambar 6). Tepung singkong tanpa pre gelatinisasi mempunyai puncak kurva yang runcing, sedangkan perlakuan pre gelatinisasi mampu merubah puncak kurva menjadi tumpul. Pre gelatinisasi $80^{\circ} \mathrm{C}$ memberikan puncak kurva amilograf yang lebih landail dibandingkan suhu $90^{\circ} \mathrm{C}$, dan pre gelatinisasi $90^{\circ} \mathrm{C}$ mempunyai puncak yang lebih landai dari pada pre gelatinosasi $100^{\circ} \mathrm{C}$. Tepung singkong tanpa pre gelatinisasi mempunyai laju

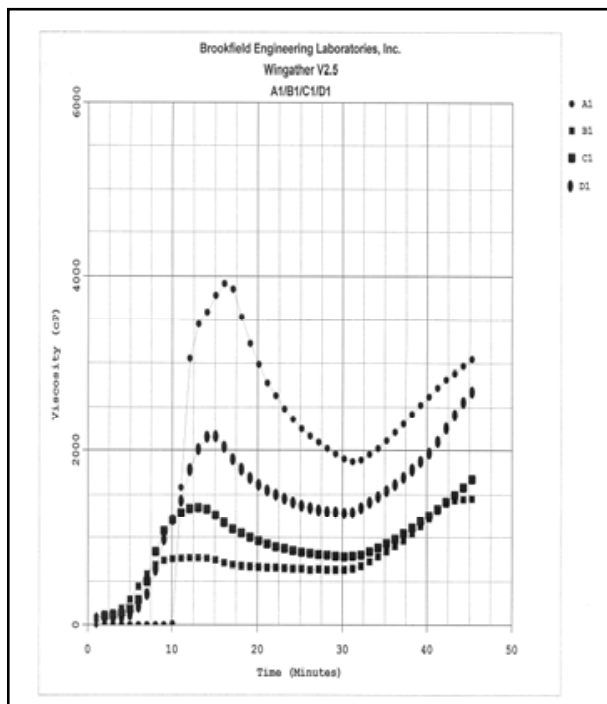

Keterangan:

$\mathrm{A}=$ Tepung Tanpa Pre gelatinisasi,

$\mathrm{B}=$ Tepung Pre Gelatinisasi $100^{\circ} \mathrm{C}$

$\mathrm{C}=$ Tepung Pre Gelatinisasi $90^{\circ} \mathrm{C}$

$\mathrm{D}=$ Tepung Pre Gelatinisasi $80^{\circ} \mathrm{C}$

\section{Gambar 6. Kurva Amilografi Tepung Singkong}

ketahanan yang lebih rendah selama proses pemanasan/ pengolahan. Menurut Champbell et al. (1950) dalam Muharram (1994) bentuk kurva amilograph dapat tajam, sempit atau lebar tergantung pada laju pembengkakan dan ketahanan granula pati terhadap kepecahan. Pati dengan puncak tajam dan sempit membutuhkan pengawasan yang ketat selama pengolahan/pemanasan. Tepung dengan puncak lebar atau plateu lebih disukai karena menghasilkan pembengkakan yang seragam.

Viskositas balik adalah tepung singkong pre gelatinisasi $90^{\circ} \mathrm{C}$ mempunyai viskositas balik yang rendah yaitu 326.40 Cp. Viskositas balik yang rendah menunjukkan bahwa pasta tepung mempunyai stabilitas melawan retrogradasi (Daramola dan Osanyinlusi, 2005).

\section{Warna}

Rerata penerimaan warna tepung singkong berkisar antara 2.6667 (netral) sampai 4.1333 (menerima). (Gambar 7).

Berdasarkan analisis ragam perlakuan pre gelatinisasi memberikan pengaruh yang sangat nyata dibandingkan tanpa pre gelatinisasi. Berdasarkan perbandingan linier otogonal terdapat perbedaan tepung singkong pre gelatinisasi dan tanpa pre gelatinisasi. Pre gelatinisasi memberikan penurunan tingkat penerimaan panelis terhadap warna tepung singkong, dibandingkan perlakuan tanpa pre gelatinisasi.

Perlakuan suhu pre gelatinisasi 


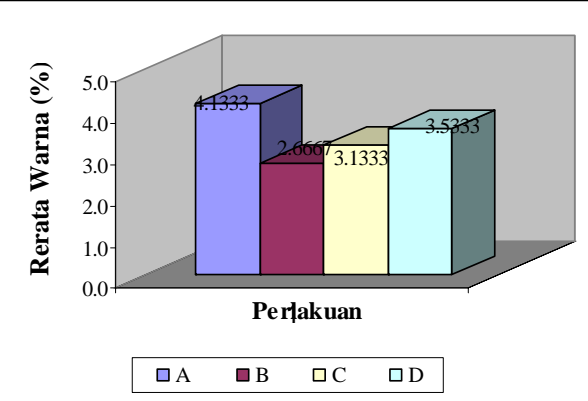

Keterangan:

$\mathrm{A}=$ Tepung Tanpa Pre gelatinisasi,

$\mathrm{B}=$ Tepung Pre Gelatinisasi $100^{\circ} \mathrm{C}$

$\mathrm{C}=$ Tepung Pre Gelatinisasi $90^{\circ} \mathrm{C}$

$\mathrm{D}=$ Tepung Pre Gelatinisasi $80^{\circ} \mathrm{C}$

\section{Gambar 7. Grafik Rerata Warna Tepung Singkong}

yang berbeda memberikan pengaruh yang sangat nyata terhadap penerimaan warna. Berdasarkan perbandingan

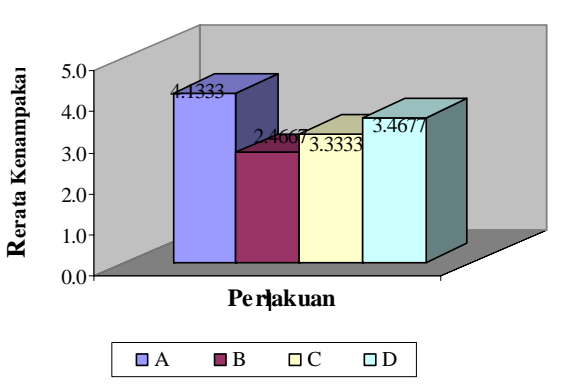

Keterangan:

$\mathrm{A}=$ Tepung Tanpa Pre gelatinisasi,

$\mathrm{B}=$ Tepung Pre Gelatinisasi $100^{\circ} \mathrm{C}$,

$\mathrm{C}=$ Tepung Pre Gelatinisasi $90^{\circ} \mathrm{C}$,

$\mathrm{D}=$ Tepung Pre Gelatinisasi $80^{\circ} \mathrm{C}$

Gambar 8. Grafik Rerata Kenampakan (Tekstur) Tepung Singkong linier ortogonal pre gelatinisasi $80^{\circ} \mathrm{C}$ memberikan perbedaan yang sangat nyata dibandingkan perlakuan pre gelatinisasi pada suhu $90^{\circ} \mathrm{C}$. Pre gelatinisasi $80^{\circ} \mathrm{C}$ meningkatkan skor penerimaan warna 3.5333 (menerima) daripada pre gelatinisasi $90^{\circ} \mathrm{C}$ yaitu 3.1333 (netral).

Tingkat penerimaan warna berhubungan dengan nilai derajat putih dari tepung singkong. Perlakuan tanpa pre gelatinisasi mempunyai tingkat penerimaan yang lebih tinggi dibandingkan pre gelatinisasi karena mempunyai derajat putih yang lebih tinggi. Perlakuan pregelatinisasi secara umum menurunkan derajat putih tepung, walaupun dengan perlakuan suhu yang berbeda akan mempengaruhi nilai derajat putih tepung singkong. Tepung singkong singkong tanpa perlakuan pre gelatinisasi memberikan kadar derajat putih tertinggi $74.100 \%$, sedangkan tepung dengan perlakuan pre gelatinisasi $100^{\circ} \mathrm{C}$ memberikan derajat putih terendah $69.5667 \%$ (Gambar 5).

\section{Kenampakan (Tekstur)}

Rerata penerimaan kenampakan (tekstur) tepung singkong berkisar antara 2.4667 (tidak menerima) sampai 4.1333 (menerima) (Gambar 8).

Berdasarkan analisis ragam perlakuan pre gelatinisasi memberikan pengaruh yang sangat nyata dibandingkan tanpa pre gelatinisasi. Berdasarkan perbandingan linier ortogonal kontras pre gelatinisasi memberikan perbedaan penerimaan kenampakan (tekstur) dibandingkan 
perlakuan tanpa pre gelatinisasi, terjadi penurunan tingkat penerimaan panelis terhadap kenampakan (tekstur) tepung singkong. Kondisi ini disebabkan karena perlakuan pemanasan atau parboiling pada menyebabkan perubahan struktur dan ukuran granula. Proses pre gelatinisasi mengakibatkan granula pati mengembang, dan mengalami perubahan bentuk, meskipun tetap pada suatu lapisan atau fragmen yang melingkupinya. Proses pre gelatini asi ini bersifat ireversibel, dimana pati yang telah mengalami gelatinisasi tidak dapat kembali pada kondisi semula. Menurut Light (1999) pregelatinisasi merupakan salah satu teknik modifikasi fisik yang dapat mengatur ukuran partikel. Annison dan Topping (2000) menyatakan bahwa gelatinisasi terdiri dari dua tahap proses yaitu suspensi pati yang dipanaskan pada suhu $60-70^{\circ} \mathrm{C}$ sebagian granula akan mengembang. Ketika suhu dinaikkan menjadi $90^{\circ} \mathrm{C}$ granula akan mengembang seluruhnya dan kehilangan bentuknya, meskipun pati masih terdiri dari suatu fragmen yang melingkupinya.

Perlakuan suhu pre gelatinisasi yang berbeda memberikan pengaruh yang sangat nyata terhadap penerimaan kenampakan. Pre gelatinisasi $100^{\circ} \mathrm{C}$ memberikan skor penerimaan terendah yaitu 2.4667 (tidak menerima). Suhu pre gelatinisaisi 90 dan $80^{\circ} \mathrm{C}$ memberikan penerimaan yang lebih baik. Pre gelatinisasi $80^{\circ} \mathrm{C}$ meningkatkan skor penerimaan kenampakan yaitu 3.4677 (netral). Menurut Light (1999) dan Huang,
(1998) temperatur adalah faktor penting pada proses pengolahan (gelatinisasi) pati. Temperatur dan waktu pengolahan (gelatinisasi) tepat, akan memberikan derajat pengembangan granula yang sesuai dan memberikan sifat yang diinginkan.

\section{Aroma}

Rerata penerimaan aroma tepung singkong berkisar antara 3.200 (netral) sampai 3.8000 (menerima) (Gambar 9).

Berdasarkan analisis ragam perlakuan tanpa pre gelatinisasi memberikan pengaruh yang sangat nyata dibandingkan perlakuan pre gelatinisasi. Berdasarkan perbandingan linier ortogonal terdapat perbedaan penerimaan aroma tepung pre gelatinisasi dan tanpa pre gelatinisasi. Perlakuan pre gelatinisasi memberikan sedikit penurunan tingkat penerimaan

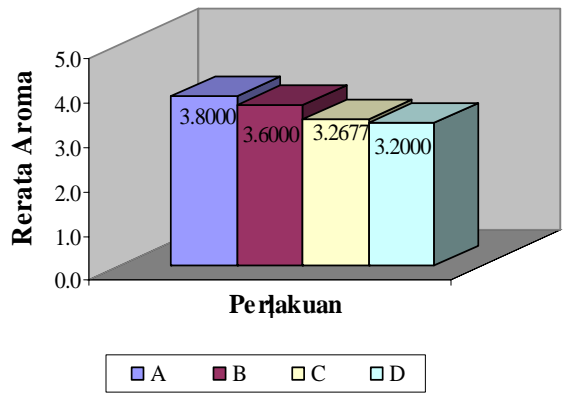

Keterangan:

$\mathrm{A}=$ Tepung Tanpa Pre gelatinisasi,

$\mathrm{B}=$ Tepung Pre Gelatinisasi $100^{\circ} \mathrm{C}$,

$\mathrm{C}=$ Tepung Pre Gelatinisasi $90^{\circ} \mathrm{C}$,

$\mathrm{D}=$ Tepung Pre Gelatinisasi $80^{\circ} \mathrm{C}$

Gambar 9. Grafik Rerata Aroma Tepung Singkong 
panelis terhadap aroma tepung singkong.

Perlakuan suhu pre gelatinisasi $100^{\circ} \mathrm{C}$ memberikan pengaruh yang nyata dibandingkan suhu $90^{\circ} \mathrm{C}$, sedangkan perlakuan pre gelatinisasi $90^{\circ} \mathrm{C}$ memberikan pengaruh yang tidak nyata dibanding kan suhu $80^{\circ} \mathrm{C}$. Pre gelatinisasi pada suhu $90^{\circ} \mathrm{C}$ dan $80^{\circ} \mathrm{C}$ memberikan tingkat penerimaan terhadap aroma yang hampir sama yaitu netral

\section{KESIMPULAN DAN SARAN}

\section{Kesimpulan}

1. Terdapat perbedaan yang nyata antara tepung singkong tanpa pre gelatinisasi dan pre gelatinisasi terhadap karakteristik kadar air, kadar HCN, kadar amilosa dan derajat putih. Begitupula dengan penerimaan organoleptik, terdapat perbedaan yang nyata antara tepung singkong tanpa pre gelatinisasi dan pre gelatinisasi terhadap penerimaan warna, kenampakan dan tekstur.

2. Pada sifat amilografi terdapat perubahan karakteristik antara tepung tanpa pre gelatinisasi dan pre gelatinisasi. Perlakuan pre gelatinisasi mampu menurunkan suhu dan waktu awal gelatinisasi, suhu dan waktu gelatinisasi (saat granula pecah), viskositas dingin, dan viskositas balik.

3. Perlakuan suhu pre gelatinisasi $\left(80^{\circ} \mathrm{C}, \quad 90^{\circ} \mathrm{C} \quad\right.$ dan $\left.\quad 100^{\circ} \mathrm{C}\right)$ memberikan karakteristik yang berbeda terhadap sifat amilografi, kadar amilosa, derajat putih, dan penerimaan organoleptik (warna, kenampakan (tekstur), dan aroma).

4. Perlakuan pre gelatinisasi $90^{\circ} \mathrm{C}$ merupakan perlakuan terbaik dengan karakteristik kadar air 11,9333\%; kadar HCN 10.7833 ppm.; kadar pati 76.7400\%; kadar amilosa $11.9267 \%$; derajat putih 71,3667\%; suhu dan waktu awal gelatinisasi $30^{\circ} \mathrm{C}$ selama 1 menit; suhu dan waktu gelatinisasi $80^{\circ} \mathrm{C}$ selama 13 menit; viskositas maksimum $1350.40 \mathrm{Cp}$; viskositas balik $326.40 \mathrm{Cp}$; organoleptik warna netral (3.1333); organoleptik kenampakan netral (3.3333); dan tekstur netral (3.2677).

\section{Saran}

1. Perlu dipelajari tentang pengaruh waktu dam suhu pre gelatinisasi terhadap karakteristik tepung singkong

2. Perlu dipelajari tentang penggunaan tepung singkong pre gelatiniasai pada bahan pangan seperti kue, cake, kerupuk, dll.

\section{DAFTAR PUSTAKA}

Anonymous. 2000. Tapioca (Cassava) Starch. International Starch Institute Science Park, Aarhus. Denmark

Anonymous. 2005. High Quality Cassava Flour. Integrated Cassava Project. Nigeria.

Annison, G and Topping D. L. 2000. 
Nutritional Role of Resistant Starch ; Chemical Structure vs Physiology Fuction. J. Nutr.14. p: 297-320.

AOAC. 1989. Official Methods of Analysis of The Association of Official Analytical Chemist. 25 ${ }^{\text {th }}$ Ed., Publisher AOAC Inc., US.

Balagopalan, C. 2002. Cassava Utilization in Food, Feed and Industry. Cassava : Biology Production an Utilizion. $\mathrm{p}$ : 301318.

Belitz H., D. and W. Groszh . 1987. Food Chemistry. Spinger-Verlag, Berlin.

Chuzel, G.; N Zakhia, and M., P., Cereda. 1994. The Potential For New Cassava Products in Brazil. Cassava Flour and Starch: Progress in Research and Development p: 299-303.

Daramola, B., and Osanyinlusi, S., A. 2006. Production, Characterization, and Application of Banana (Musa spp) Flour in Whole Maize. African Journal of Biotechnology Vol 5 (10) : 992995.

Huang, D. P. 1998. New Perspective on Starch and Derivatives for Snack Applications. National Starch and Chemical Company Bridgewater, New Jersey.

Light, M., Joseph. 1999. Modified Food Starch : Why, What, Where and How. The American Association of Cereal Chemists, Inc.

Moorthy, S.,N.; J. Rickard and J. M. V. Blanshard. 1996. Influence of Gelatinization Characteristics of Cassava Starch and Flour on the Textural Properties of Some Food Product. Cassava Flour and Starch: Progress in Research and Development p: 150-154.

Muharam, S. 1992. Sifat Karakteristik Fisiko-Kimia dan Fungsional Tepung Singkong (Manihot esculenta Crantz) dengan Modifikasi Pengukusan, Penyangraian dan Penambahan GMS serta Aplikasinya dalam Pembuatan Roti Tawar. Skripsi FATETA-IPB, Bogor.

Padmaja, G.; C. Balagopalan; S.N. Moorthy; and V., P., Potty. 1996. Yuca Rava and Yuca Porridge : The Funtional Properties and Quality of Two Novel Cassava Poducts. Cassava Flour and Starch: Progress in Research and Development p: 323-330.

Sastrosupadi, Adji. 1999. Rancangan Percobaan Praktis Bidang Pertanian. Penerbit Kanisius, Yogyakarta 
